\title{
Framing Performance Magic: The Role of Contract, Discourse and Effect
}

\section{Todd Landman}

Professor of Government

University of Essex

Visiting Professor of Performance Magic

University of Huddersfield

\begin{abstract}
A wide continuum of genres in performance magic has developed since the Victorian period, including stage magic, street magic, close-up magic, comedy magic, mentalism, bizarre and mystery entertainment. Each of these genres frames its performance on a different contract between the performer and the audience, the discourse used during performance and the effect on the audience both in terms of its perception of what has transpired and the personal meaning attached to the effect. This article examines this interplay between contract, discourse and effect in theory and practice. The article constructs a typology of performance magic which is then explored through an examination of audience perception and feedback from a drama workshop and focus group conducted at the University of Huddersfield in October 2012. The group experienced three performances framed around the idea of the magician, the mentalist, and the mystic, and the ensuing discussion revealed a wide range of insights into these different framings of performance. The reactions and ensuing discussions involved different understandings of trust, plausibility, explanation, authority, and dynamic interaction.
\end{abstract}

\section{KEYWORDS}

Frame; Contract; Discourse; Effect; Magic; Mentalism; Mystery Entertainment. 


\section{INTRODUCTION ${ }^{1}$}

The popularity of performance magic ${ }^{2}$ has waxed and waned since the Victorian period, when magic was brought off the streets and made 'respectable' through such publications and manuals for learning magic as the seminal work from Professor Hoffmann Modern Magic. The street trickster, juggler, buffoon, and jester was transformed into the tailcoat-adorned 'gentlemen magician' who would dazzle audiences through full stage shows, vaudeville acts, and themed shows, such as those performed in Britain by Maskelyne and Cooke in the great Egyptian Hall in Piccadilly between 1873 and 1904. In the United States, audiences saw the arrival of Harry Houdini, one of the most famous magicians in the world whose performances evolved from his early days of straight conjuring and manipulation to escapology and public stunts, to anti-spiritualist crusades and the exposure of fake mediums (Kalush and Sloman, 2007). Alongside more traditional manipulation (e.g. Dai Vernon, Cardini, and Slydini) and illusion shows (Harry Blacktone Sr., Harry Blackstone, Jr., and David Copperfield), the $20^{\text {th }}$ century also saw the emergence of psychic and mind reading shows (e.g. Maurice Fogel, David Berglas, and the Amazing Kreskin), 1970s hippie magic from Canadian magician Doug Henning, the street magic of David Blaine, the psychological illusions of Derren Brown, and the 'rock and roll' magic of Criss Angel. Hidden somewhat more in the shadows, 'bizarre' magicians have combined occult themes with mind reading and metaphysical concerns to bring 'spooky' performances of psychic power, dark forces, demonic assistance, and themes framed around death, retribution, evil and fear (e.g. Charles Cameron, Tony Andruzzi, and T. A. Waters).

These different strands of performance magic have variously become fashionable and then less popular as performers seek out new audiences and audiences seek out new forms of entertainment. Like the different strands in other performing arts (music, drama, comedy), these genres have distinctive communities and subcultures, as practitioners try to establish hegemony of one form of performance magic over others, or seek to construct separate identities around their stage persona and approaches to performance magic. Close-up card and coin magicians, and stage illusionists $^{3}$ and manipulators ${ }^{4}$ do not typically associate with mainstream

\footnotetext{
${ }^{1}$ I am very grateful to Nik Taylor, David Wainwright and The University of Huddersfield for providing the opportunity to host the drama workshop in the Milton Theatre on 13 October 2012. I am also grateful to Madelon Hoedt for attending the workshop and transcribing the entire recording of the three performances and ensuing discussion.

${ }^{2}$ By performance magic I mean any form of intentional deception through any means to create the appearance of inexplicable phenomena for entertainment purposes.

${ }^{3}$ Stage illusionists typically use large props, such as boxes, cabinets, cages, animals, glamorous assistants and dancers, as well as fire, explosions, and swords among other dramatic props to produce magical effects.

${ }^{4}$ Manipulators will use balls, playing cards, silks, doves, rings and other props that are used alongside deft sleight of hand and dextrous manipulation to produce magical effects.
} 
'mentalists' ${ }^{5}$, who in turn are not keen to associate with bizarrists or psychic readers. ${ }^{6}$ Like academic disciplines, these practitioners often sit at 'separate tables' and harbour muttered resentments towards their fellow performers (see Almond, 1988). To the outsider, these various distinctions can be lost or unimportant as the ticketbuying public simply seek out high quality entertainment and high quality performers who enchant them, fill them with wonder, and transport them to another place for the duration of the performance.

At a deeper level, such divisions are maintained through different uses of framing by performers, who establish different kinds of performance contracts with their audiences that are then reinforced through particular kinds of discourses, which in turn have different kinds of effects on their audiences. In drawing on the field of communications and the study of social movements in my own field of comparative politics, ${ }^{7}$ I see frames as the intentional and delimiting ways in which a magician constructs a performance, including the persona, choice of props, layout of the performance area, and type of material that is performed. I see contract as both an explicit and implicit relationship that is established between the performer and the audience, and which varies according to the overall frame. Discourse involves both the use of language, the actual choice of words and construction of meaning through 'practices that shape a particular community of social actors,' which in this case includes the performer and the audience (see Howarth, 2000, pp.1-5; Glynos and Howarth, 2007). Indeed, as we shall see, there is great variation across different types

\footnotetext{
${ }^{5}$ As will be demonstrated in this article, a mainstream mentalist performs inexplicable mind reading feats without the appearance of manipulation and often with nothing more than simple objects found in any popular stationery store.

${ }^{6}$ Indeed, within Psycrets: The British Society of Mystery Entertainers (www.psycrets.org.uk), an international not-for-profit professional association for mentalists, bizarrists, readers and other allied arts, there are palpable divisions between the 'mainstream' mentalists on the one hand and the bizarrists and readers on the other. The rift typically involves the role for public disclaimers about what is being done in any performance, where mainstream mentalists typically claim that they have no psychic ability whatsoever and bizarrists and readers openly claim they do have such powers or remain vague about what abilities are on display. Such divisions and the arguments that support them are reinforced though virtual communities and on-line forums of users who range from those who have little to no professional performance experience to those who are full time professional performers engaged in more than 250 shows per year.

${ }^{7}$ Within one strand of research on social movements, where framing theory and concepts from dramaturgy have been borrowed, there is a mounting body of evidence that shows that the ways in which struggles are framed helps explain their relative success or failure in mobilizing support (Tarrow, 1994; Benford and Hunt, 1995; Della Porta and Diani, 1999; Benford and Snow, 2000; Griggs and Howarth, 2002; Bob, 2005). Equally aggrieved groups experience different levels of success depending on how their struggles have been framed. In The Marketing of Rebellion, Clifford Bob (2005) shows that one group of aggrieved Ogoni people in Nigeria (as a result of oil exploration activities of Shell) were successful in attracting international attention to their plight when they switched their frame from one of environmental degradation to one of human rights violations. Such findings have been demonstrated across a variety of issues areas that have been the subject of large scale collective action.
} 
of performance magic in the degree to which the audience is involved in the cocreation of the performance. Finally, effect is the impact the performance has on the audience and includes not only the magical effect itself (e.g. disappearance, transformation, penetration, levitation, etc.), but also the emotional and postperformance impact on the audience.

It is this role of framing and its relation to contract, discourse and effect that is the subject of this article. From the choice of props and performance materials to the choice of words, performance magic can exhibit great variation in the relationship between the performer and the audience member. Indeed, as we shall see, even the use of the words 'audience', 'spectator' and 'trick' are problematic for many performers who prefer to engage with 'participants' and 'querents' with whom they do 'experiments' or 'demonstrations'. This renaming of what I call 'performance agents' and their discursive acts (Howarth, 2000) is a conscious strategy of linguistic construction that changes the fundamental contract between the performer and his or her audience. What people experience and how they seek to account for what they have experienced also changes as a result.

In addressing this deeper understanding of framing, contract, discourse and effect, I designed a 'controlled focus group' experiment using 18 undergraduate drama students at the University of Huddersfield. The drama students were exposed to three different kinds of magical performance at three 'separate tables': (1) the magician, (2) the mentalist and (3) the mystic. None of the drama students had a working knowledge of performance magic and the entire group witnessed all three different performances. ${ }^{8}$ At the magician's table, they saw classic magical routines and effects that used mainstay props of the close-up magician: coins, cards, balls, cups, boxes, and even a Rubik's Cube. At the mentalist's table, they experienced mainstream mentalism that used objects typically found in the office or home: books, paper, pens, envelopes, clipboards, a briefcase, dice and a large drawing pad. At the mystic's table, they were subjected to tales of travel, history, philosophy and metaphysical systems of magical correspondence, while engaging with cats-eye crystals, pendulums, photographs, antiques, books and boxes. I then engaged in a semi-structured dialogue with the students after each table, which was followed by a short break before moving on to the next table. In this way, the students were exposed to three kinds of performance magic and were allowed to reflect on their experience and articulate their views about each genre.

The controlled focus group work and feedback sessions revealed a strong role for contract, discourse, and effect in performance magic. The same performer carried out three separate performances, each with its own contract, discourse and effect, while

\footnotetext{
${ }^{8}$ None of the students had ever seen a live magical performance either, a point which was significant in the cognitive processing of what they experienced in the workshop.
} 
the feedback and discussion revealed fascinating insights into how audiences experience magic, including questions relating to trust, belief, explanation, intellectual engagement and entertainment value. In order to demonstrate this general set of findings, the paper proceeds in four sections. The first section provides a typology of performance magic and argues that there is a significant role for framing that involves contract, discourse and effect in relation to audience perception of and reaction to different genres of performance magic. The second section examines each of the three tables that were used in the drama workshop in terms of the actual table and its objects, the contract between the performer and the audience, the frame and identity created through discourse, and the reactions to the effects that were performed. These discussions are illustrated with pictures from the event of each table, selected quotations from the participants, and cross-cutting themes from the three separate sessions. The final section summarises the preliminary lessons that can be drawn from this exercise and the areas for further research on genres of performance magic.

\section{A TYPOLOGY OF PERFORMANCE MAGIC}

Performance magic has evolved considerably from its 'juggler' and marginal origins thousands of years ago to a contemporary thriving and diverse community of practitioners, creators, commercial suppliers, television programmes, and live shows around the world. There is a healthy popularity evident from a large number of magical societies (e.g. The Magic Circle, ${ }^{9}$ The International Brotherhood of Magicians, ${ }^{10}$ and The Society of American Magicians ${ }^{11}$ ), magic conventions (e.g. the annual meeting of the International Federation of Magic Societies, or FISM ${ }^{12}$ and the annual convention organised by the Blackpool Magician's $\left(\mathrm{Club}^{13}\right.$ ), on-line communities (e.g. The Magic Café ${ }^{14}$, Talk Magic, ${ }^{15}$ The Magic Bunny ${ }^{16}$ ), magic magazines (e.g. Magicseen, ${ }^{17}$ Genii Magazine, ${ }^{18}$ and Magic Magazine ${ }^{19}$ ), and increasing number of mainstream television shows, such as the recent syndicated shows Phenomenon (e.g. in the United States, Israel, and Turkey ${ }^{20}$ ), the British Broadcasting Corporation's series The Magicians ${ }^{21}$ and The Sorcerer's Apprentice, ${ }^{22}$ Independent TV's

\footnotetext{
${ }^{9}$ www.themagiccircle.co.uk

${ }^{10}$ www.magician.org

11 http://magicsam.com/

12 http://fism.org/

${ }^{13}$ www.blackpoolmagic.com

${ }^{14}$ Www.themagiccafe.com

${ }^{15}$ www.talkmagic.co.uk

${ }^{16}$ WwW.magicbunny.co.uk

${ }^{17}$ www.magicseen.co.uk

18 http://geniimagazine.com/

${ }^{19}$ http://www.magicmagazine.com/

${ }^{20}$ http://www.imdb.com/title/tt1117549/

${ }^{21}$ http://www.bbc.co.uk/programmes/b019fyjl

$22 \mathrm{http}: / /$ www.bbc.co.uk/programmes/b007t0wc
} 
Fool Us $s^{23}$ featuring famous Las Vegas magicians Penn and Teller, and Channel 4's ongoing scheduling of Derren Brown's television shows and live theatre performances in the United Kingdom. ${ }^{24}$

Across this wide community of practitioners, there is an equally wide diversity of genres of performance magic that includes stage illusions, manipulation, close-up magic, street magic, comedy magic, mentalism, psychological illusionism, theatrical mentalism, and bizarre magic. Each of these genres has key distinguishing features and offers something different to its audience. Each genre is framed differently in terms of advertisements, claims and billing for live performances, contract with the audience, and the discourse used during performance. They each have a different impact on their audience, and their practitioners are perceived differently by the general public. To illustrate these differences more fully, I provide an outline of these genres formally within a workable typology that delineates them according to a number of key features.

To begin, I divide the different genres of performance magic into three main groups: (1) magic, (2) mentalism, and (3) mystery entertainment. The magic group is further divided into (1.a) stage illusions, (1.b) stage manipulation, and (1.c) close-up and street magic. The mentalism group is further divided into (2.a) psychic-mesmerism and (2.b) psychological illusionism. The mystery entertainment group is further divided into (3.a) theatrical mentalism and (3.b) bizarre magick. ${ }^{25}$ The main features that delineate these main groups and subgroups of performance magic are: (1) their typical kind of effects (i.e. what they do in performance), (2) the typical materials and props that the use, (3) the main frame they adopt, (4) the contract between the performer and the audience, (5) the engagement with the audience, and the (6) the discourse they adopt. This article is concerned primarily with the role of contract, discourse and effect as part of the overall frame of performance, but the other delineating features outlined here are also important.

Table 1 provides a summary of the typology using these different features to delineate across the groups and subgroups. The main differences are first apparent in looking across the typical effects that each sub-group includes. While stage illusion, manipulation, close-up and some bizarre performances share a number of very similar effects (e.g. production, vanish, reappearances, penetration, transposition, etc), the two mentalism sub-groups and theatrical mentalism are markedly different, where their focus is solely on the power of the mind (e.g.

\footnotetext{
${ }^{23} \mathrm{http}: / / w w w . f o o l u s . c o . u k /$

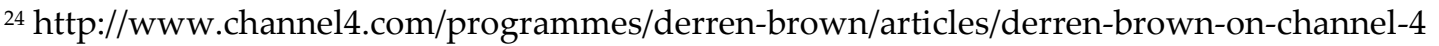

25 This final type of performance magic adopts the occult spelling of 'magick', which is a popular word used among 'bizarrists', or the practitioners of bizarre magick. The word was very popular within the late $19^{\text {th }}$ century re-emergence of the occult and occult societies, such as Madame Blavatsky's Theosophical Society and Aleister Crowley's Golden Dawn (see Albanese, 2008).
} 
telepathy, ESP, precognition, prediction, psychokinesis, and telekinesis, etc.). ${ }^{26}$ The materials and props vary greatly as well, where the two types of mentalism differ the most in their use of highly ordinary materials, such as pens, paper, pads, and other common objects found in any office supply store. The real differentiating features in the table are frame, contract and discourse. Four out of the seven subgroups are framed in terms of mere entertainment that does not ask the audience to believe in magic, but to suspend its disbelief for the duration of the performance. Stage illusionists, manipulators, and close-up or street performers engage their dextrous skills, specialised props, and sleight of hand to produce their magical effects, but they do not claim that what they are doing is in any way 'real'. Rather, they invite the audience to sit back and enjoy the display while at the same time producing inexplicable effects. Indeed, the style of engagement with the audience tends to be more passive than active, which is to say the manifestations are meant to be observed rather than co-created.

Psychological illusionists and other 'straight ahead' mentalists openly claim that they have no psychic ability but rather rely on deception, manipulation of thoughts, and powers of suggestion to achieve the appearance of psychic manifestation. In his show An Evening of Wonders, Derren Brown openly claims before a 'swami' mind reading demonstration where he answers personal questions that the audience has sealed in envelopes, '... and please remember ladies and gentlemen, I have no psychic ability whatsoever.' He then proceeds to reveal the inner most thoughts and desires of a very larger number of audience members for over twenty minutes before becoming exhausted and collapsing on stage. Anecdotally, I attended one of these shows at the Regent Theatre in Ipswich, Suffolk, and on the way out of the show, I overhead one of the audience members say, 'I don't care what he said, he is the real deal, he is psychic!'

\footnotetext{
${ }^{26}$ The esoteric word for the power of the mind is also 'mentalism', which has been used by any performance magician who uses a range of methods to achieve demonstrations of the power of the mind, such as telepathy, ESP, precognition, prediction among others. For more on the esoteric use of mentalism, see Marsh and Hoke (2008), Atkinson (2011), Segno (2012), Hill (2013).
} 
Table 1. A Typology of Performance Magic

\begin{tabular}{|c|c|c|c|c|c|c|c|c|}
\hline & \multicolumn{3}{|l|}{ 1. Magic } & \multicolumn{2}{|l|}{ 2. Mentalism } & \multicolumn{3}{|c|}{ 3. Mystery Entertainment } \\
\hline & $\begin{array}{l}\text { 1a Stage } \\
\text { illusions }\end{array}$ & $\begin{array}{l}\text { 1.b } \\
\text { Manipulation }\end{array}$ & $\begin{array}{l}\text { 1.c Close-up \& } \\
\text { street magic }\end{array}$ & $\begin{array}{l}\text { 2.a Psychic- } \\
\text { Mesmerism }\end{array}$ & $\begin{array}{l}\text { 2.b } \\
\text { Psychological } \\
\text { illusionism }\end{array}$ & $\begin{array}{l}\text { 3.a Theatrical } \\
\text { mentalism }\end{array}$ & 3.b Bizarre Magi & \\
\hline $\begin{array}{l}\text { Typical } \\
\text { Effects* }\end{array}$ & $\begin{array}{l}\text { Levitation } \\
\text { Penetration } \\
\text { Transposition } \\
\text { Production } \\
\text { Vanish } \\
\text { Reappearance } \\
\text { Transformation } \\
\text { Destruction } \\
\text { Restitution }\end{array}$ & $\begin{array}{l}\text { Production } \\
\text { Vanish } \\
\text { Reappearance } \\
\text { Multiplication } \\
\text { Transposition } \\
\text { Transformation }\end{array}$ & $\begin{array}{l}\text { Levitation } \\
\text { Penetration } \\
\text { Transposition } \\
\text { Production } \\
\text { Vanish } \\
\text { Reappearance } \\
\text { Transformation } \\
\text { Destruction } \\
\text { Restitution }\end{array}$ & $\begin{array}{l}\text { Telepathy } \\
\text { ESP } \\
\text { Precognition } \\
\text { Prediction } \\
\text { Mind reading } \\
\text { Clairvoyance } \\
\text { Clairaudience } \\
\text { Hypnosis } \\
\text { Mesmerism } \\
\text { Psychokinesis } \\
\text { Telekinesis }\end{array}$ & $\begin{array}{l}\text { Telepathy } \\
\text { ESP } \\
\text { Precognition } \\
\text { Prediction } \\
\text { Mind reading } \\
\text { Hypnosis }\end{array}$ & $\begin{array}{l}\text { Telepathy } \\
\text { ESP } \\
\text { Precognition } \\
\text { Prediction } \\
\text { Mind reading } \\
\text { Clairvoyance } \\
\text { Clairaudience } \\
\text { Hypnosis } \\
\text { Mesmerism } \\
\text { Psychokinesis } \\
\text { Telekinesis } \\
\text { Psychic } \\
\text { readings }\end{array}$ & $\begin{array}{l}\text { Levitation } \\
\text { Penetration } \\
\text { Transposition } \\
\text { Production } \\
\text { Vanish } \\
\text { Reappearance } \\
\text { Transformation } \\
\text { Destruction } \\
\text { Restitution } \\
\text { Storytelling } \\
\text { Psychic } \\
\text { readings }\end{array}$ & $\begin{array}{l}\text { Telepathy } \\
\text { ESP } \\
\text { Precognition } \\
\text { Prediction } \\
\text { Mind reading } \\
\text { Clairvoyance } \\
\text { Clairaudience } \\
\text { Hypnosis } \\
\text { Mesmerism } \\
\text { Psychokinesis } \\
\text { Telekinesis } \\
\text { Spiritualism } \\
\text { Demonism }\end{array}$ \\
\hline $\begin{array}{l}\text { Typical } \\
\text { Materials }\end{array}$ & $\begin{array}{l}\text { Boxes } \\
\text { Animals } \\
\text { Cages } \\
\text { Power saws } \\
\text { Guillotines } \\
\text { Cabinets } \\
\text { Dancers } \\
\text { Glamorous } \\
\text { assistants }\end{array}$ & $\begin{array}{l}\text { Cards } \\
\text { Coins } \\
\text { Balls } \\
\text { Silks } \\
\text { Rings } \\
\text { Flowers } \\
\text { Cigarettes } \\
\text { Light bulbs } \\
\text { Doves }\end{array}$ & $\begin{array}{l}\text { Cards } \\
\text { Coins } \\
\text { Balls } \\
\text { Silks } \\
\text { Rings } \\
\text { Notes } \\
\text { Borrowed } \\
\text { objects }\end{array}$ & $\begin{array}{l}\text { Paper } \\
\text { Pens } \\
\text { Trays } \\
\text { Boxes } \\
\text { Briefcases } \\
\text { Easels } \\
\text { Books } \\
\text { Newspapers } \\
\text { Magazines } \\
\text { Chairs } \\
\text { Cutlery }\end{array}$ & $\begin{array}{l}\text { Paper } \\
\text { Pens } \\
\text { Trays } \\
\text { Boxes } \\
\text { Briefcases } \\
\text { Easels } \\
\text { Books } \\
\text { Newspapers } \\
\text { Magazines } \\
\text { Chairs }\end{array}$ & $\begin{array}{l}\text { Antiques } \\
\text { Books } \\
\text { Lamps } \\
\text { Desks } \\
\text { Artefacts } \\
\text { Photographs } \\
\text { Carpets } \\
\text { Clocks } \\
\text { Bookcases } \\
\text { Leather satchels } \\
\text { Vases } \\
\text { Bottles }\end{array}$ & $\begin{array}{l}\text { Skulls } \\
\text { Crosses } \\
\text { Boxes } \\
\text { Crystal balls } \\
\text { Spirit lamps } \\
\text { Spirit cabinets } \\
\text { Tarot cards } \\
\text { Pendulums } \\
\text { Swords } \\
\text { Axes } \\
\text { Candles } \\
\text { Bowls } \\
\end{array}$ & $\begin{array}{l}\text { Scales } \\
\text { Knives } \\
\text { Syringes } \\
\text { Blood } \\
\text { Fire/flames } \\
\text { Wands } \\
\text { Staves } \\
\text { Robes } \\
\text { Cloths } \\
\text { Symbols } \\
\text { Chalices }\end{array}$ \\
\hline
\end{tabular}




\begin{tabular}{|c|c|c|c|c|c|c|c|}
\hline Frame & $\begin{array}{l}\text { Magic as } \\
\text { conjuring and } \\
\text { prestidigitation }\end{array}$ & $\begin{array}{l}\text { Magic as } \\
\text { conjuring and } \\
\text { prestidigitation }\end{array}$ & $\begin{array}{l}\text { Magic as } \\
\text { conjuring and } \\
\text { prestidigitation }\end{array}$ & Psychic power & Psychology & $\begin{array}{l}\text { Psychic } \\
\text { Collective } \\
\text { unconscious } \\
\text { Plurality of } \\
\text { explanations }\end{array}$ & $\begin{array}{l}\text { Occult magick } \\
\text { Spirit contact } \\
\text { Demon/angel contact }\end{array}$ \\
\hline Contract & $\begin{array}{l}\text { Suspend } \\
\text { disbelief }\end{array}$ & $\begin{array}{l}\text { Suspend } \\
\text { disbelief } \\
\text { Physical } \\
\text { dexterity }\end{array}$ & $\begin{array}{l}\text { Suspend } \\
\text { disbelief } \\
\text { Physical } \\
\text { dexterity }\end{array}$ & Real power & $\begin{array}{l}\text { Plausibility } \\
\text { Psychological } \\
\text { manipulation } \\
\text { Subliminal } \\
\text { suggestion }\end{array}$ & $\begin{array}{l}\text { Real power } \\
\text { Expand } \\
\text { understanding }\end{array}$ & Real occult power \\
\hline $\begin{array}{l}\text { The } \\
\text { engagement } \\
\text { with the } \\
\text { audience }\end{array}$ & $\begin{array}{l}\text { Passive } \\
\text { viewing }\end{array}$ & $\begin{array}{l}\text { Passive } \\
\text { viewing }\end{array}$ & $\begin{array}{l}\text { Interactive } \\
\text { participation }\end{array}$ & $\begin{array}{l}\text { Interactive } \\
\text { participation }\end{array}$ & $\begin{array}{l}\text { Interactive } \\
\text { participation }\end{array}$ & $\begin{array}{l}\text { Interactive } \\
\text { participation }\end{array}$ & $\begin{array}{l}\text { Passive viewing } \\
\text { Interactive participation }\end{array}$ \\
\hline Discourse & $\begin{array}{l}\text { 'Magic' } \\
\text { 'Trick' } \\
\text { 'Illusion' } \\
\text { 'Spectator' }\end{array}$ & $\begin{array}{l}\text { 'Magic' } \\
\text { 'Trick' } \\
\text { 'Illusion' } \\
\text { 'Spectator' }\end{array}$ & $\begin{array}{l}\text { 'Magic' } \\
\text { 'Trick' } \\
\text { 'Illusion' } \\
\text { 'Spectator' } \\
\text { 'Stunt' } \\
\text { 'Endurance' }\end{array}$ & $\begin{array}{l}\text { 'Psychic' } \\
\text { 'Demonstration' } \\
\text { 'Experiment' } \\
\text { 'Participant' }\end{array}$ & $\begin{array}{l}\text { 'Neuro- } \\
\text { linguistic } \\
\text { programming' } \\
\text { 'Body language' } \\
\text { 'Suggestibility' } \\
\text { 'Demonstration' } \\
\text { 'Experiment' } \\
\text { 'Participant' }\end{array}$ & $\begin{array}{l}\text { 'Mysterious' } \\
\text { 'Demonstration' } \\
\text { 'Experiment' } \\
\text { 'Participant' } \\
\text { 'Akashic } \\
\text { records' } \\
\text { 'Collective } \\
\text { unconscious' } \\
\text { 'Empathy' }\end{array}$ & $\begin{array}{l}\text { 'Occult' } \\
\text { 'Ritual' } \\
\text { 'Angelic/demonic summoning' } \\
\text { 'Communication with the dead' } \\
\text { 'Mystery schools tradition' } \\
\text { 'Hermeticism' } \\
\text { 'Spiritualism' }\end{array}$ \\
\hline $\begin{array}{l}\text { Popular } \\
\text { exemplars }\end{array}$ & $\begin{array}{l}\text { Harry } \\
\text { Blackstone } \\
\text { David } \\
\text { Copperfield } \\
\text { Siegfried and } \\
\text { Roy } \\
\text { Hans Blok }\end{array}$ & $\begin{array}{l}\text { Juliana Chen } \\
\text { Scott Penrose } \\
\text { Roy Davenport }\end{array}$ & $\begin{array}{l}\text { David Roth } \\
\text { Michael } \\
\text { Ammar } \\
\text { Michael } \\
\text { Vincent } \\
\text { Will Houstoun } \\
\text { David Blaine } \\
\text { Dynamo }\end{array}$ & $\begin{array}{l}\text { Kreskin } \\
\text { Maurice Fogel } \\
\text { David Berglas } \\
\text { Luke Jermay }\end{array}$ & $\begin{array}{l}\text { Derren Brown } \\
\text { Banachek } \\
\text { Richard } \\
\text { Osterlind } \\
\text { Andy Nyman } \\
\text { Jon Stetson } \\
\text { Chuck Hickok }\end{array}$ & $\begin{array}{l}\text { Christian } \\
\text { Chelman } \\
\text { Paul Voodini } \\
\text { Todd Landman } \\
\text { Christian } \\
\text { Cagigal } \\
\text { Professor BC }\end{array}$ & $\begin{array}{l}\text { Charles Cameron } \\
\text { Tony Andruzzi } \\
\text { Roni Shachnaey } \\
\text { Professor Rigomorto } \\
\text { Todd Robbins } \\
\text { Neil Tobin }\end{array}$ \\
\hline
\end{tabular}

Sources: Author's own construction. *List of effects draws on Lamont and Wiseman (1999). 
The website for Banachek claims that, 'His [Banachek's] talents are so incredible that he is the only mentalist ever to fool scientists into believing he possessed "Psychic powers" then later reveal he was fooling them.' 27 The popular US television show The Mentalist has a very similar premise, while many psychological illusionists like Derren Brown and Banachek have joined forces with scientific sceptics such as Richard Dawkins and James Randi to expose frauds and issue challenges to anyone claiming to have psychic ability (including faith healing and evangelism) to be examined under scientific conditions. ${ }^{28}$ The 'challenge' mentality has framed a number of performances and has been the premise of the Phenomenon and Fool Us television series. The message is very clear: psychic manifestations are replicated but never actually done.

There is thus a shared frame between psychological illusionists and magicians regarding the role of 'magic', or the unknown method for producing inexplicable effects; however, the discourse and effects are markedly different. Magicians perform 'tricks', 'illusions', and 'magical feats' for an audience of 'spectators', while psychological illusionists engage in a series of 'demonstrations', 'experiments', and 'tests' with 'participants'. They use everyday objects to co-create their effects with participants, who are brought forward to make choices, think of words and numbers, and reveal their inner thoughts through a variety of different means. The effects include mind reading, remarkable coincidences (synchronicity), precognition, prediction, and other demonstrations of extra-sensory perception (ESP), as well as psychokinetic effects such as the bending of keys, coins, spoons, knives and forks.

In contrast to magicians and psychological illusionists, 'mystery entertainers' adopt three framing strategies: (1) openly claim what they are doing is real, (2) leave the claim implicit, or (3) remain ambiguous about the process through which they are producing their effects. They assume that within a performance context, no real disclaimer is required, and that the audience can make up its own mind about what is being experienced. An oft-heard remark from such performers is as follows: 'At the beginning of a play or film, one does not see a disclaimer saying that the scenes you are about to see involve actors playing a part, where no real murder is committed and no real supernatural phenomena are produced.' This range of frames allows mystery entertainers to concentrate on the mystery of their performances without making reference to any disclaimer or implicit contract as seen with magicians and psychological illusionists. Mystery entertainers thus adopt performance persona that show considerable variation: intuitionists, synchronists, phasmologists, tarologists, enchanters, metaphysicians, curators, mystics, mediums,

\footnotetext{
${ }^{27} \mathrm{http}: / /$ www.banachek.org/nonflash/index.htm

${ }^{28}$ For more on the sceptics challenges, see the James Randi Educational Foundation

(http://www.randi.org/), which in many ways, carries on the exposure work against fraudulent mediums conducted by Harry Houdini in the latter years of his life (Houdini, 1924; Kalush and Sloman, 2007).
} 
and psychic entertainers. Far from explaining away the mystery through an appeal to plausible frames, mystery entertainers increase the implausibility of what they are doing through an appeal to lesser known powers and ideas.

Among mystery entertainers, there is a clear difference between the theatrical mentalists' and the bizarrists. Theatrical mentalists typically locate their performances through an appeal to history and historical objects, or what Christian Chelman, calls 'Hauntiques'. Chelman is a magician and 'curator' who has assembled a collection of magical objects in his Brussels-based Surnateum, ${ }^{29}$ where visitors are treated to a dazzling display of artefacts, divination tools, objects, and books that suggest the possibility of magic through various manifestations. Within his collection is the only genuine vampire hunting kit, necromantic skull, shaman outfits, voodoo implements, casting bones from Mongolia, and even an amulet found on a Neanderthal, which Chelman proudly asserts is the world's oldest magical object. Theatrical mentalists engage in storytelling and an appeal to the injustices in history, the horror of Victorian institutions, the research into psychic phenomena, among other frames. They allow their participants to engage with historical artefacts and produce inexplicable effects ranging from divining personal information, past life regression, and pendulum experiments to communing with spirits through various quasi-scientific instruments, such as Edison spirit lights. ${ }^{30}$

In contrast, bizarre magicians make much more explicit reference to the occult. Drawing on a rich tradition of real magic, the mystery school, hermetic philosophy, Satanism, demonic and angelic conjuration, and organised occult societies, bizarrists engage in storytelling performances that often involve themes of raising (or communicating with) the dead, making pacts with the devil, cheating death (gallows are popular), and meeting one's fate at the day of judgement. Bizarrists use historical objects and artefacts, but unlike theatrical mentalists also perform 'magical' effects (transpositions, transformations, penetrations, fire, potions, etc.) that are used to illustrate large narratives about fate, luck, divine intervention and the use of curses.

Clearly, with any typology, the lines of distinction between different categories can be very blurred. Indeed, there are many performers who happily blend and mix these different styles, but there are many who are keen to maintain a 'pure' identity for their frame, and will reject performing particular effects that are inconsistent with their persona and character. There is much magical miscegenation that occurs as these different communities talk to one another and interact at magical conventions and on line forums. It is also the case that many performers start in one category of

\footnotetext{
${ }^{29}$ See http://www.surnateum.org/

${ }^{30}$ Thomas Edison, the inventor of the light bulb believed that the energy from the spirit world could manifest itself through making light bulbs flicker to signal the presence of spirits. Another such instrument is the 'spiritometer' invented by Ropert Hare, a professor of chemistry at the University of Pennsylvania in the $19^{\text {th }}$ Century.
} 
magic and evolve toward others. Indeed, my own trajectory, which informed the design of the drama workshop, has been from magic to mentalism to mystery entertainment. And it was this evolution that led me to design the workshop that is the focus of the next section.

\section{THE THREE TABLES: THE TYPOLOGY PRESENTED}

The typology developed in the previous section of this article has been the basis for my thinking on how to carry out an instructive workshop for non-magical theatre students to explore the role of contract, discourse and effect. My design was intended to draw out stark differences between the different categories of performance magic through performance itself, while intentionally controlling the use of contract, discourse and effect. The idea of separate tables seemed a nice way to gauge audience reaction to and participation in different forms of performance magic. ${ }^{31}$ The group experience was 'controlled' in the sense that the entire group saw each performance consecutively and was given the opportunity to compare across the different performances. The results are by no means methodologically robust and other experimental designs suggest themselves for future research, but the findings obtained here are worth sharing in order to develop the argument presented thus far. This section thus describes the setup of each table, the contract between the audience and me, the frame and identity that I sought to create, the effects I performed and the reactions that I received from the group.

\section{The Magician}

The first table was set up to convey the sense of classic close-up magic. The table was covered with a coloured cloth and in the centre a black close-up mat ${ }^{32}$ to denote the focussed performance area. Scattered around the mat were some coins and playing cards, while on the corner of the table a small briefcase of props. On the mat was a small easel on which I had a deck of playing cards and next to the easel, a fully mixed Rubik's Cube (see Figure 1). The physical layout of the table invites curiosity while my positioning primarily behind the table established a particular frame of the 'magician' and his 'audience', where there was a degree of formal separation between the performance space and the audience of spectators. While some of the effects were done interactively, many were purely visual effects with patter that were observed passively (a key difference with the two other tables). The mat and case are also evocative of the alchemical roots to modern performance magic, as they are both the 'space' within which and the tools with which transformation takes place.

\footnotetext{
${ }^{31}$ I was also partly influenced by a seminal essay by political scientist Gabriel Almond called 'separate tables' and which referred to the paradigm wars in my own discipline.

32 A close up mat is a small rectangular shaped foam mat with rubber backing that is used by close up magicians to display coins, cards and small objects used for the performance of magical effects.
} 


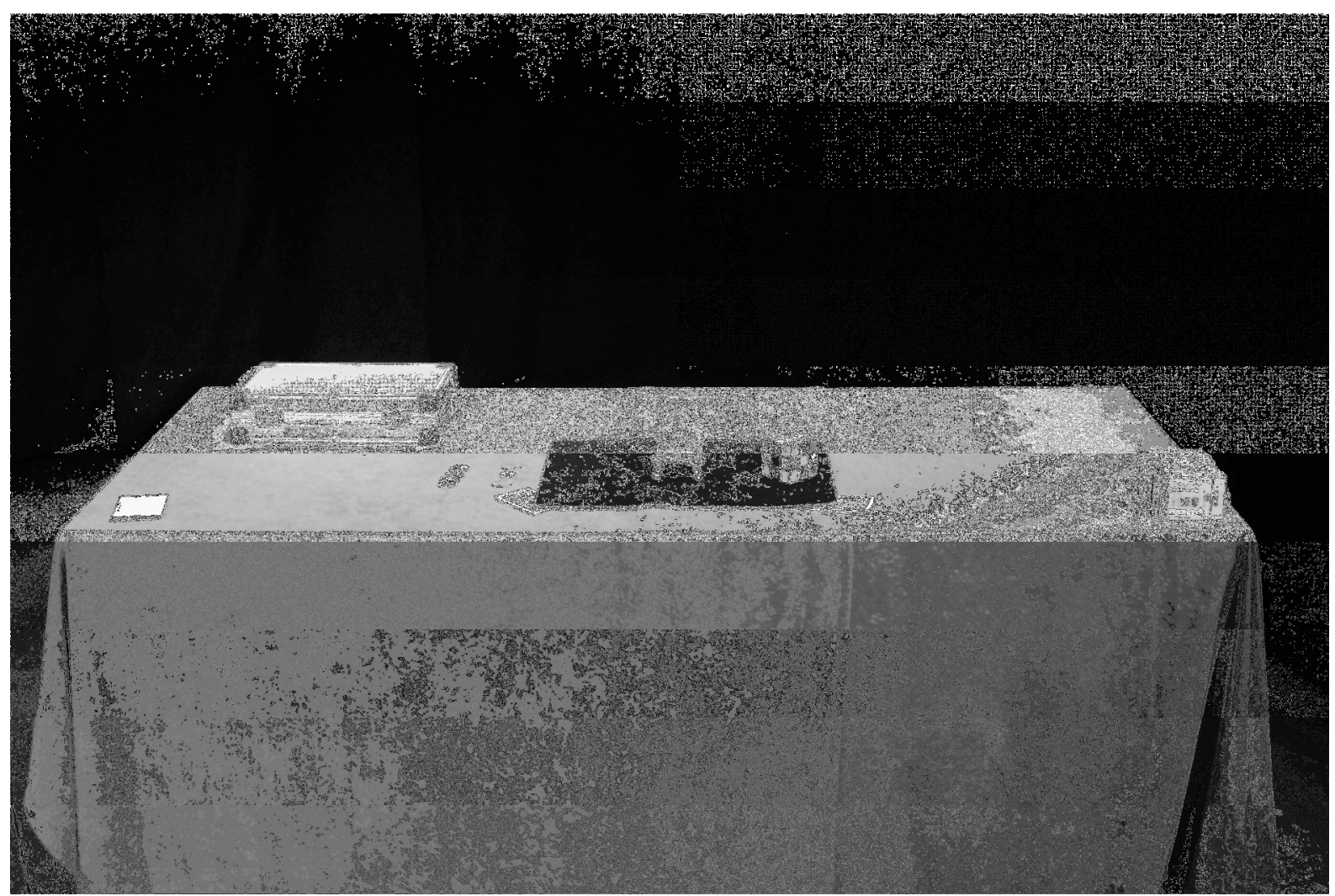

Figure 1. The Magician's Table

I began with the Rubik's cube, which I mix and discuss as one of the most frustrating toys one could ever give a child and asked the audience for feedback on their own experiences trying to solve the cube. A general consensus emerges with regard to the frustration and I then throw the cube in the air to have land in my hand completely solved. The visual and emotional impact of this effect cannot be underestimated as it is frequently met with a collective and very audible gasp. The workshop participants were no exception. This particular effect neatly establishes credibility that magical things will happen and that I am a capable magician. This was followed by some card-based routines (four aces are immediately found from a shuffled deck, the four aces magically reverse themselves one by one in my fingertips, and the four aces 'assemble' in one packet on the table that was freely chosen by a spectator).

After the cards, I proceeded to make four coins jump from one closed fist to another and move around magically beneath four playing cards on the mat. I made a selection of international coins move miraculously between my hands and my pockets. I made 'rings' out of three playing cards by tearing out their centres and then proceeded to link and unlink the them, followed by a torn and restored link to finish. I then moved from the cards and coins to sponge balls that multiplied and vanished in a spectator's hand to a game with a cup and ball that resulted in the audience never really knowing where the ball was or never being prepared for the appearance of two much larger balls under the cup. For the final effect, I borrowed a 
ring from one of the young women in the group, made it vanish from underneath a silk scarf only to find that it was inside three locked boxes sitting on the mystic table across the stage in plain view throughout the performance.

These effects were all performed with the implicit contract that I was going to show them a wide range of amazing things. From the Rubik's Cube to the ring inside the locked boxes, my persona was one of a performer with a lot of skill and magical feats to share with my audience. My style was light and cheerful, as well as encouraging them to enjoy what they were watching (e.g. 'please watch and don't blink because you might miss this...'). Their applause and expressions of surprise were genuine (which we captured in photographs of the event), while their comments were fascinating. The first piece of feedback that was of interest concerned that fact that none of them had ever seen live magic performed before. The only access to date had been through television. One of the participants $\left(\mathrm{Zoe}^{33}\right)$ said that for that very reason she 'trusted' me. Our exchange ${ }^{34}$ at this point is worth sharing:

ZOE: When we started this module I started to research a lot more, and I've seen it, but I'm quite sceptical, so when I watch it on TV, I don't trust it, especially when you watch people like Derren Brown...

TODD: So what do you mean by trust? Tell me about that word.

ZOE: Because it's on TV, there's so many different tricks they can put in; it's not like it's live, watching it now...

TODD: Do you trust me?

ZOE: Yeah.

TODD: What does it mean to trust me, because I'm actually lying, cheating and stealing up there...

ZOE: I can believe this sort of magic; I know the hand didn't go in the box and we definitely know that she [the volunteer whose ring had vanished and reappeared] wasn't planted, because we all came in together, but when you're watching it on TV, there's so many different things that you can put in, and I just don't believe it, I refuse to believe it.

This exchange shows that live performance magic can develop experiences and feelings relating to trust and belief. Zoe trusted the fact that I had not pre-arranged anything with the woman who volunteered her ring (I really had not) and on that basis believed that the ring had vanished from the scarf (it really did) and reappeared from the three locked boxes (it really did). The others were desperate to know how these effects were achieved and offered explanations for what they had

\footnotetext{
${ }^{33}$ This is not her real name for reasons of anonymity.

${ }^{34}$ This is a direct transcript of the audio recording taken on the day of the workshop 13 October 2012. The transcription was done by Madelon Hoedt. The direct quotations in this section have changed the names to protect the identity of the participants.
} 
seen, but gave up with the ring effect. These ideas of trust, belief, and explanation would recur through the performances and discussion at the next two tables.

\section{The Mentalist}

The mentalist table was intentionally sparse and unremarkable. There was no table cloth, no mat and nothing to suggest any hint of 'magic' per se. Rather, there was a black flight case, a wooden executive suggestion box, some paperback novels, some dice, a mobile phone, pads of paper, pens and a bottle of mineral water. Once the participants had returned from a short break and settled comfortably into their seats, I immediately wrote something on a piece of paper and placed it folded on the table and then strode into the seating area and began asking people to think of two digits numbers. Once offered, I opened the paper to reveal that I had accurately predicted the choice of one of the participants by name. Without pause, I asked another participant to visualise a concert and choice of an instrument from the orchestra, where her choice matched exactly an instrument that was written down on a piece of paper that had been sealed in an envelope under her chair (and no one else's chair). This rapid fire and highly interactive display continued with the correct divination of words chosen from books, names of family members and pets, drawings of personal objects, and an uncanny demonstration were the total of three four digit numbers supplied by the participants equalled my birth date printed in my passport that had been in the possession of one of the participants throughout. I also had five participants each choose a different coloured die and through a process of 'reading' divined the colour they had selected.

The pace, delivery, style and overall frame of this performance was radically different from the first. I was 'walking amongst' them, interacting, asking for them to think of things, choose things, write things down and take part in what could be described as a 'co-created' performance. There were no flourishes, no vanishes, no productions, but plenty of surprises and uncanny outcomes which provoked strong reactions. My claim was a mixture of direct mind reading, character reading and an understanding of body language. This claim was never explicitly made but demonstrated. The initial adjectives used by the participants were 'weird', 'very cool', 'awesome', 'confusing' and 'uncomfortable'. One participant who liked this performance more than the first claimed, 'it involved us more.' Another remarked, 'It felt more academic; you felt more like a professor.' And perhaps one of the more telling comments came from a participant called Brittany ${ }^{35}$ :

Also, you stood in front of the table, rather than being behind; getting in contact with people, you touched people, you got up to their faces... It felt like, rather than being serious and doing tricks, you were with us.

\footnotetext{
${ }^{35}$ Like Zoe, this name is fictitious to protect the identity of the student.
} 


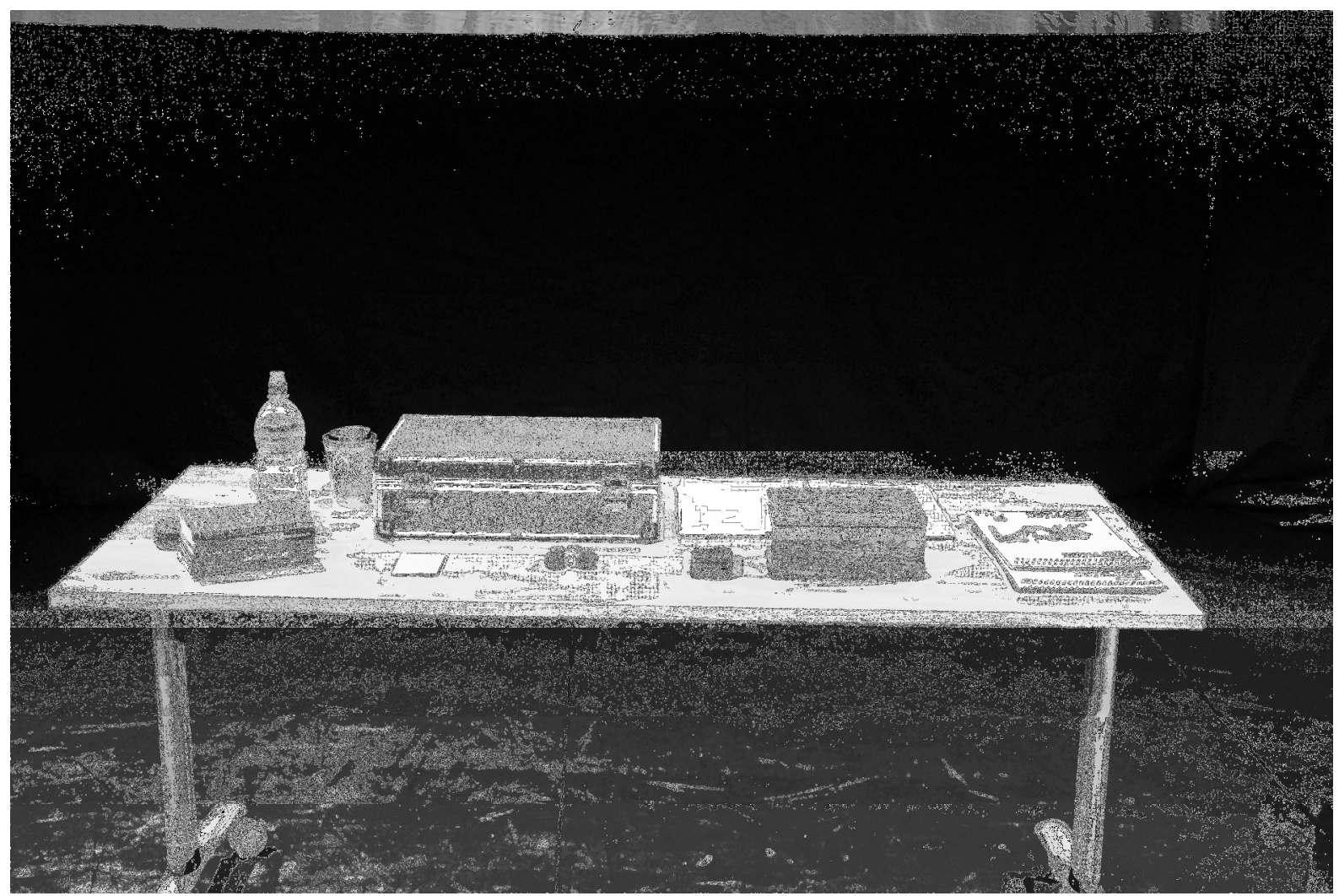

Figure 2. The Mentalist's Table

Beyond these reactions, I had another long round of exchanges with Zoe, who was the most confused by the second performance. She was particularly worried about two of the demonstrations: the coloured dice and my simultaneous duplication of her drawing. Again, our exchange is worth sharing here:

ZOE: Because I can't be hypnotised; I'm not submissive at all, I'm very aware of what's going on...

TODD: You're very aware of what's going on...

ZOE: And the dice thing, I thought, "I'm going to be one of the last ones, because I can't be read, he's going to narrow it down so it's an easy choice," and I was one of the last ones, but that [refers to drawing duplication] I was convinced you'd get it wrong, because I know what's going on, I won't let people in...

But somehow, I did manage 'to get in', which was troubling her. Continuing our exchange, it became clear that Zoe had seen Derren Brown on television, and remarked:

ZOE: I know that he [Derren Brown] does a lot of subliminal messaging, so, like, the music he plays when you come in or stuff that's in the theatre, but this is nothing, there wasn't anything...

TODD: No music... 
ZOE: There's nothing, no pictures hanging up... [...]

Zoe's quest for explanation and to make sense of everything she had experienced is very telling. After the Magician's Table she claimed that she 'trusted' me and 'believed' what she saw (but did not believe in magic) and after the Mentalist's Table, she was adamant that she could not be hypnotised or 'read', and yet remained perplexed that in the absence of music or stage settings, I had nonetheless 'read' her. I have had similar strong reactions (both positive and negative) to this performance framing. In March 2011 in Milton Keynes one of the participants, whose childhood pet's name I correctly divined became very agitated and exclaimed 'you could not possibly have known that as my mother named it!' and then proceeded to avoid me and not to speak to me for the rest of my time there. A year later at Cambridge University during a similar divination, the participant said 'when you were reading my mind, I had a warm glow in my heart.'

\section{The Mystic}

The final table offered something completely different altogether. It was covered in multiple cloths from around the world. On the table were books, boxes, a small travel case, a sand timer, a bust of Aristotle, and a selection of differently coloured cats-eye crystals (see Figure 3). As the participants filed back in from their break they found me seated next to the table deeply absorbed in a book. As they settled in to their seats, I snapped the book shut and proceeded to talk about mind-body dualism, esoteric correspondences, the philosophy of the mind and Jung's notion of the 'collective unconscious'. I experimented with a pendulum with one participant, which correctly divined the location of an object in one of her hands. Using the 'underlying harmonic vibrations' of the cats-eye crystals, I was able to determine which of the participants had selected each crystal, even though their choices had been hidden from sight. I tapped into the historical and psychic energy of the victims and survivors of the 1912 Titanic disaster in an uncanny display of empathy and coincidence. Throughout, the frame was one of the scholar magician and philosopher who advocated a certain 'metaphysical plurality' and left any explanation ambiguous at best.

The words used to describe this performance included 'creepy', 'strange', 'educational', 'the lecturer', 'the philosopher', and 'more scientific'. And the everkeen Zoe remarked:

There's more of a context involved. You've got stories, you've got philosophy, you've got things that have happened in the past... Various people, scholars... 


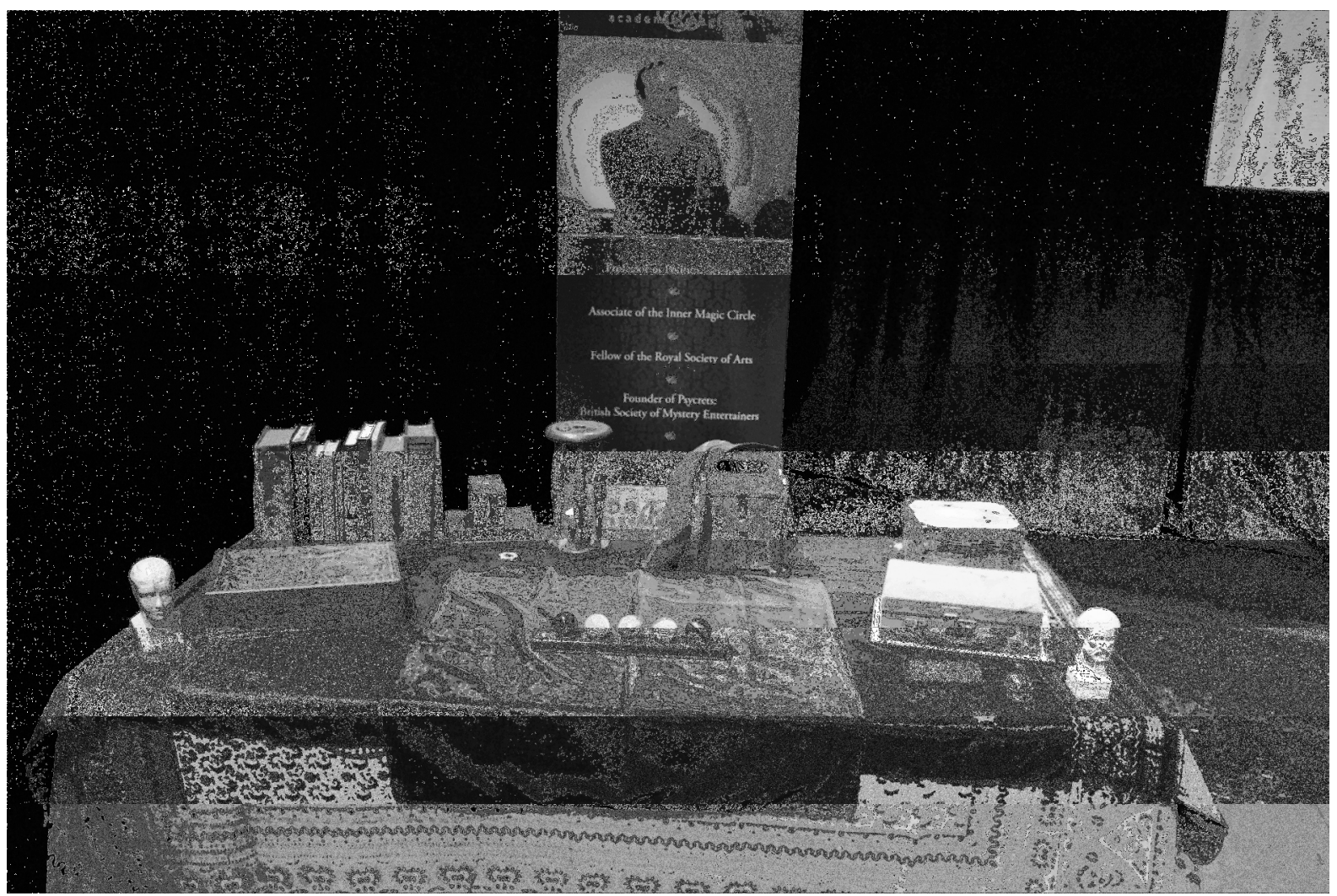

Figure 3. The Mystic's Table

For others (Larissa and Simon ${ }^{36}$ ) the final table did not really interest them. My exchanges with both went as follows:

LARISSA: Out of all these tables, this was the most boring to me. When I first came in, before we sat down, I looked at all the tables, and this one just looked boring.

TODD: Why is it boring?

LARISSA: Because I'm not really interested in, like... I really like stupid stuff, so... The objects on the table, like, the heads and the shiny balls, they don't...

TODD: They don't do anything for you? Who else feels the way Larissa does? The techies? [a portion of the participants were theatre technical students, not drama students] No problem, that's a really interesting observation, I'm really interested in that. Simon, what did you think? Do you like this stuff?

SIMON: No.

I find these last comments fascinating in reaction to a 'thicker' frame that was grounded in real philosophical ideas and historical references, mixed with a pinch of Dan Brown-esque esotericism. Some of the participants enjoyed these types of references while others clearly did not. It may be that their generation and/or age

${ }^{36}$ These names are also fictitious to protect the students' identity. 
cohort simply could not connect with the material. At the end of the three sessions, however, the clear preference for the entire group was for The Mentalist. The demonstrations were short, sharp and to the point. They involved the thoughts and choices of the participants, and an overall dynamic interaction kept the pace of the performance, while the framing was one of light psychological illusionism. The workshop 'worked' in the sense that I was able to present three different framings to the same group, and I was able to elicit three different kinds of reactions and responses as a consequence.

\section{SUMMARY AND IMPLICATIONS}

Without delving into the actual methods that lie behind the achievement of the effects discussed here, this article has shown that framing matters for the experiences of performance magic. The contract with the audience interacts with the language that is used and the effects that are performed. Individuals are bombarded by different frames every moment of every day, and they engage in different frames as they interact with different people. Jungian practitioners speak of people wearing different 'masks' as they engage with different people throughout their every day routine. Performance magic is no exception, as the both the typology and the workshop discussion have tried to show here. The layout of the three tables, the staging of the performance and the interactive nature of each performance created a different experience for the participants, while their struggle for explanation of what they had seen was in line with the frame that had been created.

By switching frames between The Magician, The Mentalist and The Mystic, I was able to elicit different experiences, different reactions, and the struggle for different explanations of what had been experienced. The general typology of performance magic advanced in this article coupled with the insights gained from the workshop participants, suggest that audiences for performance magic will respond differently to different frames, where the contract between performer and audience, the discourses used to describe what is happening, and the effects that are experienced will vary depending on the frame that is adopted. Future research in this area can engage in more formal experimental design in which pre-show and post-show surveys are carried out on audiences, who are in turn exposed to different performance frames of the kind delineated in this article. It is hoped that for this inaugural issue of the Journal of Performance Magic that the insights offered here lead to continued and fruitful research on the role of framing in performance magic.

\section{REFERENCES}

Albanese, Catherine (2008) Republic of Mind and Spirit: A Cultural History of American Metaphysical Religion, New Haven: Yale University Press. 
Almond, Gabriel (1988) 'Schools and Sects in Political Science'. PS: Political Science and Politics. 21 (4) pp. 828-842.

Atkinson, William Walker (2011) The Secret of Mental Magic, Nabu Press.

Benford, Robert D. and Hunt, Scott A. (1995) 'Dramaturgy and Social Movements: The Social Construction and Communication of Power'. In Stanford M. Lyman (ed) Social Movements: Critiques, Concepts and Case-Studies London: Mcmillan, pp. 84-112.

Benford, Robert D. and Snow, David A. (2000) 'Framing Processes and Social Movements: A Review and Assessment'. Annual Review of Sociology. 26, pp. 611639.

Bob, Clifford (2005) The Marketing of Rebellion. Cambridge: Cambridge University Press.

Della Porta, Donatella and Diani, Mario (1999) Social Movements: An Introduction. Oxford: Blackwell.

Foweraker, Joe and Landman, Todd (1997) Citizenship Rights and Social Movements: A Comparative and Statistical Study. Oxford: Oxford University Press.

Griggs, Steve and Howarth, David (2002) 'An Alliance of Interest and Identity? Explaining the Campaign Against Manchester Airport's Second Runway'. Mobilization. 7 (1), pp. 43-58.

Glynos, Jason and Howarth, David (2007) Logics of Critical Explanation in Social and Political Theory. London: Routledge.

Hill, Napolean (2013) Think and Grow Rich. Tribeca Books.

Hoffman, A.J.L. (1978) Modern Magic. Dover Publications.

Houdini, Harry (1924) A Magician Among the Spirits. Fredonia Books.

Howarth, David (2000) Discourse. Buckingham: Open University Press.

Kalush, William and Sloman, Larry (2007) The Secret Life of Houdini: The Making of America's First Superhero. Atria Books. 
Lamont, Peter and Wiseman, Richard (1999) Magic in Theory: An Introduction to the Theoretical and Psychological Elements of Conjuring. University of Hertfordshire Press.

Landman, Todd (2008) Issues and Methods in Comparative Politics. London and Oxford: Routledge.

Marsh, Clint and Hoke, Jeff (2008) The Mentalist's Handbook: An Explorer's Guide to Astral, Spirit Psychic Worlds. Weiser Books.

Segno, Victor (2010) The Law of Mentalism. Kessinger Books.

Tarrow, Sidney (1994) Power in Movement. Cambridge: Cambridge University Press. 